\title{
Genetic Power of a Brazilian Three-Generation Family with Generalized Aggressive Periodontitis
}

\author{
Gisela Estela RAPP ${ }^{1}$ \\ Nicolas PINEDA-TRUJILLO² \\ Andrew McQUILLIN ${ }^{3}$ \\ Maurizio TONETTI ${ }^{4}$ \\ ${ }^{1}$ Federal University of Bahia, Salvador, BA, Brazil \\ ${ }^{2}$ University of Antioquia, Medellin, Columbia \\ ${ }^{3}$ University College London, London, United Kingdom \\ ${ }^{4}$ European Research Group of Periodontology, Brienz, Switzerland
}

\begin{abstract}
Aggressive periodontitis is a multifactorial disease with strong familial aggregation. Genetic linkage analysis is a method to localize causative or predisposing genes along the chromosome, thus helping to unravel important pathogenic pathways. Prior to applying this method, however, it is essential to estimate the power of the study design. The aim of this study was to estimate the power of a large Brazilian family with generalized aggressive periodontitis $(\mathrm{GAgP})$ for future linkage analysis. A three-generation family was seen at the Dental School of the Federal University of Bahia. A full-mouth periodontal probing at 6 sites/tooth was performed in all 23 family members. Five out of 10 siblings were affected with GAgP. A parametric simulation $(\theta=0)$ was performed on 100 replicates using the statistical software SLINK for linkage analysis. The linkage LOD score criteria for complex diseases described by Haines was adopted. There was maximum expected LOD scores of 3.56 and 3.48 at penetrance rate $F=0.98$, and both studied phenocopy rates $p=0.0$ and $\mathrm{p}=0.02$, respectively. The analyzed family showed statistical power for future genetic linkage analysis of candidate genes to GAgP.
\end{abstract}

Key Words: family study, genetic linkage, aggressive periodontitis.

\section{INTRODUCTION}

During recent years, one focus of genetic studies has been the identification and location of genes that contribute to the pathogenesis of common diseases. Periodontitis is a multifactorial inflammatory disease that leads to the destruction of periodontal tissues in the presence of infection.

Aggressive periodontitis (AgP) comprises a group of rare, often severe and rapidly progressive forms of periodontitis. In spite of its rare occurrence, $\mathrm{AgP}$ has been the focus of several investigations that aimed at understanding its etiology and pathogenesis (1). There is a distinctive tendency for $\mathrm{AgP}$ to aggregate within families. Although, in general, AgP can occur at any age, it is frequently characterized by a clinical manifestation at early age, which indicates that the responsible etiologic agents are able to cause clinically detectable levels of the disease within a relatively short time. This fact is central to the current understanding of $\mathrm{AgP}$, since it points to an infection with a highly virulent microflora and/or a high level of susceptibility to this periodontal disease. Any diagnosis of AgP requires the exclusion of the presence of systemic diseases that may severely impair host defenses and lead to premature tooth loss. Given the disproportionately high incidence of AgP within families, it is crucial to evaluate siblings and other family members of affected individuals. This form of diagnosis provides valuable information regarding the level of risk eventually shared among family members, and helps to establish the need for monitoring clinically unaffected individuals.

Segregation analysis is a method to study families in order to assess the likelihood that a certain disease is inherited as a genetic trait. One large segregation analysis on more than 100 US-American families demonstrated a prevalence of $70 \%$ of the autosomal dominant mode of inheritance of $\operatorname{AgP}(2)$. More recently, a segregation

Correspondence: Profa. Dra. Gisela E. Rapp, Rua 8 de Dezembro, 302 Ed. Franz Schubert, apto. 102, Graça, 40.150-000 Salvador, BA, Brazil. Tel/ Fax:+55-71-3235-3391. email: giselarapp@uol.com.br. 
analysis on 74 Brazilian families showed an unequivocal genetic influence on the expression of $\mathrm{AgP}$ and suggested a polygenic inheritance of the disease, with or without the participation of the environment (3). Although segregation analysis provides information about the mode of inheritance of a genetic trait, it does not identify the gene(s) involved. A successful method for detecting causative or predisposition genes is linkage analysis. One basic assumption of this method of analysis is that genes on the same chromosome segregate together at a rate related to the chromosomal distance between them, measured as recombination fraction $(\theta)$. The shorter the distance between the loci, the higher is the possibility that they will segregate together during meiotic recombination (combination of chromosome fragments from father and mother). In case two loci segregate together at a rate higher than $50 \%$, they are, to some extent, genetically linked. Thus, the strength of linkage between two analyzed loci depends on the genetic proximity between them, and can be estimated by means of logarithms of the odds (LOD score). This method has been applied with success in mapping complex diseases such as Alzheimer's disease, breast cancer and cardiovascular diseases (4). In recent years, linkage analysis proposed a genetic linkage of localized $\mathrm{AgP}(\mathrm{LAgP})$ to chromosome $1 \mathrm{q} 25$ in four multigenerational African American families (5), thus extending the spectrum of investigations of the previously reported chromosomal regions 4,6 , and $9(6,7)$. These findings, however, still require confirmation in other families and linkage studies.

An essential step prior to performing linkage analyses is to estimate the power of the study design, in other words, to determine whether the available pedigree information is sufficient to allow the detection of gene(s) underlying the trait(s) of interest. The information from such power-estimates is furthermore important to develop adequate sampling strategies, to determine the optimal study design, to identify informative individuals, and to estimate the costs of a study (8). The aim of the present study was to estimate the power of a large Brazilian family for future genetic linkage analysis of candidate genes for generalized $\mathrm{AgP}(\mathrm{GAgP})$.

\section{MATERIAL AND METHODS}

In the course of the diagnostic process of GAgP of a 37-year-old woman (proband) at the Dental School of the Federal University of Bahia, Brazil, the entire family (23 family members in total) was periodontally examined and a pedigree was constructed. The family members ranged in age from 4 to 71 years and presented mixed ethnic features related to Portuguese Caucasian and Brazilian Indian ethnicities.

In all 23 family members, a trained examiner performed a full-mouth periodontal probing at six sites/ tooth with a manual probe (CP 10 William's periodontal probe, Hu-Friedy, Chigaco, IL, USA). Five of the 10 siblings (second generation) presented the following primary criteria for aggressive periodontitis established by the American Academy of Periodontology (1): (a) except for the presence of periodontitis, the subjects were otherwise clinically healthy; (b) the subjects presented rapid attachment loss and bone destruction; and (c) familial aggregation. The clinical attachment loss in the mentioned family members was due to pocketing. In addition, routine full-mouth periapical X-rays revealed a generalized distribution of severe alveolar bone loss. In the affected siblings, the disease was classified as generalized $\mathrm{AgP}$ since at least three permanent teeth other than first molars and incisors were involved in the periodontal destruction. Both parents (first generation) were edentulous. In direct interview, the mother reported pyorrhea as the cause of tooth loss, whereas the father informed that he had lost his teeth due to caries. Consequently, the phenotype of the mother was considered positive, while it was negative for the father.

Given the age dependence of the expression of periodontitis concerning the time needed for the sequels to accumulate, family members under the age of 14 were classified as unknown phenotype (9) in order to avoid misclassification of the phenotype in the study model. None of the family members had ever received any information about their periodontal status or were submitted to periodontal treatment prior to the present study. They were not enrolled in any oral hygiene program by the time of this study either. All affected family members were non-smokers and tested negative for diabetes. There was no suspicion of any other systemic condition or of consanguinity in this family. The pedigree structure and the phenotypic outcome (affected or not affected) of the studied family is presented graphically in Figure 1.

All subjects agreed to participate in the study by means of written consent. The Brazilian Commission of Ethics in Research approved the study protocol (CONEP 12649).

The statistical analysis involved the estimation of the probability for reaching a LOD score of $Z \geq 3$. 
An autosomal dominant inheritance mode was assumed $(2,10,11)$. Three different penetrance values $(\mathrm{F}=0.98$, 0.75 and 0.50 ) and two phenocopy rates $(p=0.0$ and 0.02$)$ were tested. One hundred replicates of the studied pedigree were simulated using the software SLINK, which is a general simulation program for linkage analysis (12). For the simulations, a recombination fraction $(\Theta)=0$, allele frequencies of 0.0001 for the mutated allele and of 0.25 for each of four equally frequent allele markers were assumed. The results were evaluated following the linkage LOD score criteria described by Haines (13) for complex diseases (polygenic or multifactorial) (Table 1).

\section{RESULTS}

Maximum expected LOD score frequencies, and expected average and maximum LOD scores for the given genetic parameters in the investigated Brazilian family are presented in Tables 2 and 3. The frequency of a LOD score of 3 (evidence for genetic linkage) was $36 \%$ and $27 \%$ at penetrance rate $\mathrm{F}=0.98$ and phenocopy rates $\mathrm{p}=0.0$ and 0.02 , respectively. Maximum ELOD scores of 3.56 and 3.48 were found at penetrance rate $\mathrm{F}=$ 0.98 and phenocopy rates $\mathrm{p}=0.0$ and 0.02 , respectively.

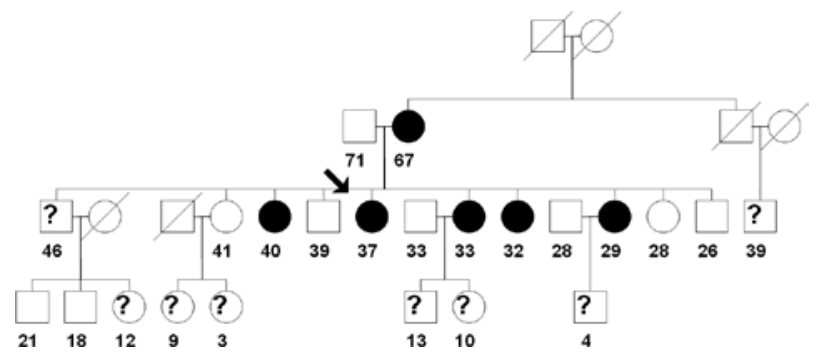

Figure 1. Pedigree structure of the studied Brazilian threegeneration family. Numbers below the symbols indicate the age of the respective family member; arrow designates the proband; open squares: unaffected males; open circles: unaffected females; filled circles: affected females; crossed-out symbols: deceased or not available family members; ? = unknown phenotype.

Table 2. Frequency (\%) of maximum ELOD scores at phenocopy rates $\mathrm{p}=0.0$ and 0.02 , and penetrance rates $\mathrm{F}=0.50,0.75$, and 0.98 .

\begin{tabular}{|c|c|c|c|c|c|c|}
\hline \multirow{2}{*}{$\begin{array}{l}\text { ELOD } \\
\text { Score }\end{array}$} & \multicolumn{3}{|c|}{$\mathrm{p}=0.0$} & \multicolumn{3}{|c|}{$\mathrm{p}=0.02$} \\
\hline & $\mathrm{F}=0.50$ & $\mathrm{~F}=0.75$ & $\mathrm{~F}=0.98$ & $\mathrm{~F}=0.50$ & $\mathrm{~F}=0.75$ & $\mathrm{~F}=0.98$ \\
\hline 1 & 59 & 58 & 76 & 39 & 58 & 61 \\
\hline 2 & 7 & 32 & 66 & 5 & 28 & 45 \\
\hline 3 & 0 & 0 & 36 & 0 & 0 & 27 \\
\hline
\end{tabular}

\section{DISCUSSION}

During the second decade of the twentieth century, the discoveries and intellectual concepts by Thomas Hunt Morgan and his students laid the groundwork for the Human Genome Project and our current attempts to identify genes that cause or predispose to human diseases. Working in the famous "fly room" at Columbia University, they discovered that chromosomes are the physical basis of heredity and that genes are specific entities arranged along the lengths of individual chromosomes. An additional important contribution was the delineation of spontaneous and induced Drosophila mutant phenotypes. Morgan et al. (14) understood that the accurate definition of the phenotype is an essential requirement for any scientific inquiry into mechanisms of heredity. Hence, what is conventionally referred to as "gene mapping" is, in fact, phenotype mapping.

Family reports are an important diagnostic tool, accepted as a diagnostic criterion by the 1999 AAP classification system. The Brazilian family analyzed in our study presented all three primary features of GAgP established by the American Academy of Periodontology (1999). In this family, there was a high sibship aggregation of $50 \%$, since 5 out of 10 siblings presented clinical features of GAgP. This finding is in agreement

Table 1. LOD scores and p values proposed by Haines (13) for a genomic screen of complex traits.

\begin{tabular}{lcc}
\hline Significance & LOD score & $\mathrm{p}$ value \\
\hline Interesting & 1 & 0.03 \\
Very interesting & 2 & 0.0009 \\
Provisional linkage & 3 & 0.00003 \\
Confirmed linkage & 4 & 0.0000008 \\
& & (at least two data sets) \\
\hline
\end{tabular}

Table 3. Average and maximum (Max) ELOD scores at phenocopy rates $\mathrm{p}=0.0$ and 0.02 , and penetrance rates $\mathrm{F}=0.50,0.75$, and 0.98 .

\begin{tabular}{|c|c|c|c|c|}
\hline \multirow{2}{*}{ F } & \multicolumn{2}{|c|}{$\mathrm{p}=0.0$} & \multicolumn{2}{|c|}{$\mathrm{p}=0.02$} \\
\hline & Mean & Max & Mean & Max \\
\hline 0.50 & 1.09 & 2.24 & 0.77 & 2.19 \\
\hline 0.75 & 1.3 & 2.96 & 1.24 & 2.87 \\
\hline 0.98 & 2.28 & $3.56^{*}$ & 1.76 & $3.48 *$ \\
\hline
\end{tabular}

*ELOD score above 3. 
with previous studies on different populations presenting this disease. Both parents of the studied family were edentulous, the mother due to pyorrhea, and the father as a consequence of caries. In the study model, hence, the phenotype was considered positive for the mother and negative for the father. Consequently, the high familial aggregation of $50 \%$ is held up even when considering both the first and the second generation. In addition to GAgP, the members of the family presented a high incidence of caries.

The maximum ELOD scores found in the studied Brazilian family ( 3.56 and 3.48 at penetrance rate $\mathrm{F}=$ 0.98 and phenocopy rates $p=0.0$ and 0.02 ; Table 3 ) are comparable to the values reported in previous studies. In a single large Scottish family, a maximum ELOD of 3.80 was described when including three different clinical liabilities of GAgP in the analysis (15). Another study, investigating four multigenerational African American families affected with a localized form of AgP, homogenized by laboratorial features of increased levels of superoxide generation and decreased chemotaxis, and the presence of Aggregatibacter actinomycetemcomitans, reported a maximum ELOD of 3.75 (16). From their findings, the authors suggested a linkage of the studied LAgP to chromosome 1q25.

Studying one large family might be a helpful approach for a multistage genotype or phenotype mapping of complex diseases. Since it is more likely that only few loci, or even a single locus, contribute to the expression of a certain disease within one family compared to the general population, these family studies strengthen the genetic model towards the same possible locus or loci. Another advantage of investigating single families over studying entire populations are lower costs once the studied family proofs to have power in detecting genetic linkage. Hence, important pathogenic pathways of complex diseases might be identified with this kind of study. The clear limitation of these single family approaches is, however, that findings of linkage in one family require confirmation through other data sets and populations before general conclusions can be drawn. The overall conclusion of this study is that the analyzed Brazilian three-generation family is suitable for future genetic linkage analysis of candidate genes for GAgP.

\section{RESUMO}

Periodontite agressiva é uma doença multifatorial que apresenta forte agregação familiar. Análise de ligação genética é um método que localiza genes que causem ou predisponham doenças ao lon- go do cromossomo e pode ser útil na descoberta de importantes mecanismos patogênicos. No entanto, antes de se realizar uma análise genética de ligação, é essencial estimar o poder do estudo delineado. O objetivo deste estudo foi estimar o poder de uma grande família apresentando periodontite agressiva generalizada para futura análise genética de ligação. Uma família de três gerações (23 membros) que procurou por tratamento periodontal na Faculdade de Odontologia da Universidade Federal da Bahia foi analisada. Em todos os membros familiares foi realizado um exame periodontal completo em seis sítios/dente em todas as unidades dentais presentes por um único examinador. Dos dez irmãos, cinco apresentaram a periodontite agressiva generalizada de acordo com o sistema de classificação da Academia Americana de Periodontia 1999. Uma simulação paramétrica $(\theta=0)$ foi realizada em 100 repetições com o uso do software SLINK para ligação genética. O escore logarítmico LOD descrito como critério para doenças complexas (poligênicas ou multifatoriais) por Haines foi adotado. Em nosso estudo foi encontrado um LOD esperado máximo de 3,56 e 3,48 na razão de penetrância $\mathrm{F}=0,98$ nas duas razões de fenocópia estudadas $\mathrm{p}=0,0$ e $\mathrm{p}=0,02$, respectivamente. A família analisada mostrou ter poder estatístico suficiente para futura análise de ligação genética de genes candidatos para periodontite agressiva generalizada.

\section{ACKNOWLEDGEMENTS}

The authors would like to thank all the family members and volunteer collaborators for their help in realizing this study. This study was financially supported by CAPES grant 2622/03-3 of the Brazilian Ministry of Education.

\section{REFERENCES}

1. Tonetti MS, Mombelli A. Aggressive periodontitis. In: Clinical Periodontology and Implant Dentistry. Lindhe J, Karring T, Lang NP (Editors). 4th ed. Oxford: Blackwell Publishing; 2003. p 216242.

2. Marazita ML, Burmeister JA, Gunsolley JC, Koertge TE, Lake $\mathrm{K}$, Schenkein HA. Evidence for autosomal dominant inheritance and race-specific heterogeneity in early-onset periodontitis. $\mathrm{J}$ Periodontol 1994;65:623-630.

3. de Carvalho FM, Tinoco EM, Govil M, Marazita ML, Vieira AR. Aggressive periodontitis is likely influenced by a few small effect genes. J Clin Periodontol 2009;36:468-473.

4. Schmidt S. Advanced parametric linkage analysis. In: Genetic Analysis of Complex Diseases. Haines JL, Pericak-Vance MA (Editors). New York: Wiley-Liss; 2006. p 255-277.

5. Li Y, Xu L, Hasturk H, Kantarci A, DePalma SR, Van Dyke TE. Localized aggressive periodontitis is linked to human chromosome 1q25. Hum Genet 2004;114:291-297.

6. Boughman JA, Halloran SL, Roulston D, Schwartz S, Suzuki JB, Weitkamp LR, et al.. An autosomal-dominant form of juvenile periodontitis: its localization to chromosome 4 and linkage to dentinogenesis imperfecta and Gc. J Craniofac Genet Dev Biol 1986;6:341-350.

7. Wang S, Sun C, Gillanders E, Wang Y, Duffy D, Bock C, et al. Genome scan for susceptibility loci to the complex disorder early onset periodontitis. Am J Hum Genet 1996;59: Abstract: 1386.

8. Li Y, Shao S, Peer M. Sample size and power. In: Genetic Analysis of Complex Diseases. Haines JL, Pericak-Vance MA (Editors). New York: Wiley-Liss; 2006. p 355-393. 
9. Trevilatto PC, Tramontina VA, Machado MA, Goncalves RB, Sallum AW, Line SR. Clinical, genetic and microbiological findings in a Brazilian family with aggressive periodontitis. J Clin Periodontol 2002;29:233-239.

10. Hodge PJ, Teague PW, Wright AF, Kinane DF. Clinical and genetic analysis of a large North European Caucasian family affected by early-onset periodontitis. J Dent Res 2000;79:857-863.

11. Li Y, Xu L, Hasturk H, Kantarci A, DePalma SR, Van Dyke TE. Localized aggressive periodontitis is linked to human chromosome 1q25. Hum Genet 2004;114:291-297.

12. Ott J. Computer-simulation methods in human linkage analysis. Proc Natl Acad Sci USA 1989;86:4175-4178.

13. Haines JL. Genomic screening. In: Approaches to Gene Mapping in Complex Human Diseases. Haines JL, Pericak-Vance MA (Edi- tors). New York: Wiley-Liss; 1998. p 243-254.

14. Aylsworth A. Defining disease phenotypes. In: Genetic Analysis of Complex Diseases. Haines JL, Pericak-Vance MA (Editors). 2nd ed. New Jersey: Wiley-Liss; 2006. p 51-89.

15. Hodge PJ, Teague PW, Wright AF, Kinane DF. Clinical and genetic analysis of a large North European Caucasian family affected by early-onset periodontitis. J Dent Res 2000;79:857-863.

16. Li Y, Xu L, Hasturk H, Kantarci A, DePalma SR, Van Dyke TE. Localized aggressive periodontitis is linked to human chromosome 1q25. Hum Genet 2004;114:291-297.

Accepted April 20, 2010 